Arhe XII, 23/2015

UDK 930.85(44)“17“"

130.2

Originalni naučni rad

Original Scientific Article

\author{
PREDRAG KRSTIĆ 1
}

Institut za filozofiju i društvenu teoriju, Univerzitet u Beogradu

\title{
ROMANTIZOVANJE ILI ROMANTIČARSKO OSPORAVANJE PROSVETITELJSTVA?
}

Sažetak: U članku se tvrdi da rani romantizam, artikulišući vlastito stanovište, upućuje prosvećenosti jednu „estetičku“ primedbu i da se ta primedba može protegnuti do duboko u dvadeseti vek. Autor rada je, posle Šlegela i njegove škole, pronalazi ne samo u Veberovoj dijagnostici institucionalizovane racionalnosti zapadne civilizacije, te u Dijalektici prosvetiteljstva Horkhajmera i Adorna i kritici ciljno orijentisanog ili instrumentalnog uma savremenosti koja je usledila, već i, na drugačiji način, kod Fukoa, braće Beme, pa čak i u filozofiji postmoderne i neopragmatizma. Zaključuje se da je svim tim orijentacijama zajednička detekcija manjka samoprosvećenosti prosvetiteljstva, izostanak njegove autoreferentne korekcije, neobračunavanje troškova ogrešenja o ono njegovo „drugo“, što onda bilo nepovratno ili ipak nekako još ispravljivo, potkopava njegov izvorni kritički i emancipatorski program.

Ključne reči: prosvetiteljstvo, romantizam, racionalnost, organizacija, dominacija, umetnost

\section{PROSVETITELJSTVO ILI ROMANTIZAM: DEFINISANJE RINGA}

Kao „problematično“ dete prosvetiteljstva, ${ }^{2}$ romantizam s ,roditeljem“ deli emancipatorsku strast ali ne i njegovu ,racionalnost“. Utoliko strast postaje žešća. Njegova pobuna može biti, kao i kada je reč o prosvetiteljstvu, metafizička ili socijalna, bunt protiv odnosa u društvu ili uopšte protiv čovekovog položaja u svetu, kao što može imati karakter utopijske ili konzervativne revolucije. Ali na izvoru, a ponekad i na kraju, uvek je kardinalno, zaoštreno, na život i smrt, odbijanje mirenja sa stvarnošću, jedna borba koja se i okončava tragičkim porazom u neravnopravnom sukobu sa onom težinom autoriteta i tradicije koji je koncentrisan u savremenim represivnim

$1 \quad$ E-mail adresa autora: krstic@instifdt.bg.ac.rs

2 Hit, D. \& D. Boreham, Romantizam za početnike, Hinaki, Beograd 2003., str. 7, 11. 
institucijama. ${ }^{3} \mathrm{U}$ takve institucije se sada smešta i prosvetiteljstvo: njegov oslobodilački poziv na privođenje razumu prelazi na stranu porobljivača.

Viljem Blejk (William Blake) Njutna (Newton) i Loka (Locke), svece (ranog) prosvetiteljstva, međaše moderne nauke čija su se postignuća smatrala nesumnjivim jemstvom opravdanosti vere u društveni progres, optužuje za nastojanje da u kavez utamniče slobodni duh ljudi i iscrpu sav život iz njega. „Umetnost je drvo života, / nauka je drvo / smrti“", ${ }^{4}$ piše on pre svega protiv dvojice slavnih zemljaka, ali i protiv francuskih ,rezonera“, protiv režima uređenog i urednog sveta. Samoostvarenje je postalo presudno u poretku koji mu nije ostavio prostor: izuzetnost, vlastita posebnost, pa gotovo ma kakva da je. Klasicističke vrednosti roditelja su samo roditeljske vrednosti. Romantizam ne samo da ne bi da ih (na)sledi, nego ni da ih zameni ma kojim drugim skupom ponuđenih vrednosti. On bi da ospori samo traganje za vrednostima ukoliko ono podrazumeva da bi one mogle biti negde pronađene a ne tek proizvedene, ukoliko se otkrivaju a ne stvaraju delatnim činom uvek jedinstvenog stvaraoca. Time bunt prerasta u nepomirljivi prkos i romantizam otvoreno odbacuje ,centralnu tezu prosvetiteljstva prema kojoj ono što je istinito, ispravno, dobro ili lepo, može biti pokazano da važi za sve ljude valjanom primenom objektivnih metoda" ${ }^{5}$

Sa romantizmom će se tako prosvetiteljstvo po prvi put suočiti sa svojom kliničkom slikom, a racionalizacija sveta koju je preduzelo razotkriti kao patologija apstraktnog analitičkog duha. On bi, u skladu s imenom, da sve razloži, jer sve vidi kao sklop, kao izvedenu sintezu. Ako je taj vivisekcijski pristup dao rezultate $u$ hemiji, ako je i pomogao da se poruši ideološka tvrđava božanske milosti, on je takođe rastočio i ljudski duh i državu. Prvi je sveo na mehanički ansambl elementarnih čulnih utisaka i predstava, a drugu na slepo operisanje individualizovanih monada bez istinskog odnosa i zajedništva. Pred furioznim naletom uma stradali su kreativni i osećajni potencijali čoveka, čulnost, spontanost i svaka posebnost. Kao što je sve transcendentno iščezlo pod tiranijom prirodnonaučnog logosa, tako je i individualna sloboda utrnula ispod opštosti zakona. Hladni, formalni, avetinjski razum prosvetiteljstva, taj, rečima Franca Šuberta (Franz Schubert), „ružni kostur bez mesa i krvi“",6 izlazi na zao glas kao uzurpator složenosti i izuzetnosti ljudskog

3 Uporediti Berlin, I., Koreni romantizma, Službeni glasnik, Beograd 2006., str. 144-145; Janjion, M., Romantizam. Revolucija. Marksizam, Nolit, Beograd 1976., str. 228-229.

4 Blake, W., “Laocoön”, http://en.wikisource.org/wiki/Laocoon_(Blake), 12.5.2011., stihovi $100-102$.

5 Berlin, I., "The Counter-Enlightenment" u Dictionary of the History od Ideas, tom 2 (priredio P. Wiener), Scribner, New York 1973, str. 109.

6 Prema Peri, M., Intelektualna istorija Evrope, Clio, Beograd 2000., str. 240. 
iskustva. Poezija, umetnost uopšte, nadređuju se nauci i filozofiji, a racionalna analiza i geometrijsko proračunavanje ustupaju mesto neposrednijem obraćanju srcu i intuitivnom prodoru u dubine života. ${ }^{7}$

Radije se sada zaziva ono tajanstveno, primitivno, elementarnije i snažnije od uma, koje nakon prosvetiteljstva i protiv njega valja galvanizovati. Namera je, makar isprva, bila da se svet „poetizuje“, a ne politizuje. „Poetizovanje“" sveta se drugačije kaže „romantizovanje“. ${ }^{8}$ Slaveći poeziju kao ,izraz imaginacije“, Šeli (Shelley) promoviše pesnike u „nepriznate zakonodavce sveta". ${ }^{9}$ Dvadeset tri godine ranije Šlegel (Schlegel) je već dao i antipolitička uputstva za ponašanje takvih zakonodavaca: „Umetnik isto tako malo sme hteti da vlada kao i da služi. On može samo da obrazuje, ništa do da obrazuje, dakle da za državu čini samo to da obrazuje vladare i sluge, da uzdiže političare i ekonome do umetnika". ${ }^{10} \mathrm{Ili}$, ako ni od toga nema vajde, makar da čuva i zastupa čovečnost u svetu koji joj nije naklonjen, da „poveže strašću i znanjem čitavo carstvo ljudskog društva, onako kako se ono rasprostire duž čitave zemlje i svog vremena", kao što kaže Vordsvort (Wordsworth) u Predgovoru Lirskim baladama. ${ }^{11}$

Utoliko nije sasvim pogrešno reći, makar za rane romantičare, da su oni u umetnosti pronašli onu instancu koja može da obnovi jedinstvo čoveka sa prirodom i društvom i ispuni prazninu koju je ostavila ubojita moć prosvetiteljske kritike. ${ }^{12}$ Produktivna moć umetnosti, moć da imaginacijom stvori čitav svet, ako se i ne suprotstavlja, pretpostavlja se destruktivnosti kritičkog

7 Uporediti Novalis, „Fragmenti“ u Romantizam (priredio Z. Gluščević), Obod, Cetinje 1967, str. 61; Frank, M., Einführung in die frühromantische Ästhetik, Suhrkamp, Frankfurt am Main 1989., str. 7-24; Bowie, A., From Romanticism to Critical Theory. The Philosophy of German Literary Theory, Routledge, London 1997., str. 65-89; Saul, N., "The Pursuit of the Subject: Literature as Critic and Perfecter of Philosophy 1790-1830" u Philosophy and German Literature, 1700-1990 (priredio N. Saul), Cambridge University Press, West Nyack 2002., str. 70-71.

8 „Svet mora biti romantizovan. Tako će se opet pronaći prvobitan smisao“ Novalis („Fragmenti“, str. 77).

9 Shelley, P. B., Defence of Poetry, http://rpo.library.utoronto.ca/content/defence-poetrypart-first-1821, 12.2.2010., §342.

10 Šlegel, F., „Fragmenti Ideje“ u Ironija ljubavi: (izbor iz dela), Zepter Book World, Beograd 1999., str 112, fragment 54.

11 Wordsworth, W., "Preface to the Lyrical Ballads", http://www.english.upenn. edu/ mgamer/Etexts/lbprose.html\#preface, 23.1.2010.

12 Beiser, F., "Early Romanticism and the Aufklärung" u What Is Enlightenment? Eighteenth-Century Answers and Twentieth-Century Questions (priredio J. Schmidt), University of California Press, Berkeley 1996., str. 318-319. 
uma. ${ }^{13} \mathrm{Na}$ umetnosti je da sada samosvesno re-kreira ono što je u „naivno“ doba bilo dato - moralno i religiozno verovanje koje integriše, jedinstvo čoveka sa prirodom i društvom - da stvori novu mitologiju (uma), da regeneriše misteriju, čar i lepotu prirode opipljivo je „romantizujući““.14

\section{PRVA RUNDA: KRITIKA INSTRUMENTALNE RACIONALNOSTI}

U dvadesetom veku „estetička“ opomena romantizma postaje naučno operativni motiv, pre svega kod Maksa Vebera (Max Weber): sa akademskom strogošću on će sada u modernom svetu prepoznati ne iščašenje istorijskog toka, već upravo sliku uznapredovale racionalnosti koju su prosvetitelji zagovarali. ${ }^{15}$ Prema Veberovom mišljenju, epohalnim „procesom racionalizacije“, koji je birokratski organizovao sve sfere društvenog života, omogućen je tehnološki napredak i materijalni prosperitet, ali je cena bila visoka: naporedni razvoj sofisticirane tehnike za „političku, društvenu, obrazovnu i propagandnu manipulaciju i dominaciju nad ljudskim bićima“. ${ }^{16}$ Svojim obožavanjem sistema, modernizatorsko „raščaravanje“ sveta je omogućilo vlast ljudi nad prirodom, ali je istovremeno umanjilo značaj pojedinca, koji je postao „mali

13 Romantičari su zapravo preuzeli Šilerovu (Schiller) dijagnozu problema i njegovu terapiju putem estetskog obrazovanja: jedino umetnost može da ujedini podeljene moći čoveka, obezbedi model vrline i inspiriše ljude na delatnost (videti Schiller, F., Ueber die ästhetische Erziehung des Menschen, in einer Reihe von Briefen, http://gutenberg.spiegel.de/buch/3355/, 3.5.2009). Prema Lavdžoju (Lovejoy), teoriju romantizma nije oblikovao tek Šlegel, nego je ona bila, takoreći, „nusprodukt“ prevladavajućeg klasicizma ranih godina poslednje decenije devetnaestog veka, a najvažniji tekst u preobraćenju Šlegela iz klasicizma u romantizam bio je Šilerov esej „O naivnom i sentimentalnom pesništvu“, koji je već ponudio „,romantičko“ opravdanje „duhovne situacije vremena“ i misije modernih pesnika (videti Lovejoy, A., „Schiller and the Genesis of German Romanticism“ u Essays in the History of Ideas, Capricorn Books, New York 1960., str. 207-227; Lovejoy, A., „The Meaning of 'Romantic' in Early-German Romanticism“ u Essays in the History of Ideas, Capricorn Books, New York 1960., str. 183-206; Schiller, F., „Über naive und sentimentalische Dichtung“, http://www. kuehnle-online.de /literatur/schiller/werke/phil/nsdichtung/, 9.5.2008).

14 Uporediti Helderlin, F., „Najstariji sistemski program nemačkog idealizma“ u $O$ pesničkoj umetnosti, Rad, Beograd 1997., str. 104-105; Šlegel, F., „Ironija ljubavi“ u Ironija ljubavi: (izbor iz dela), Zepter Book World, Beograd 1999., str. 142-146; za politički aspekt nove mitologizacije sveta videti Sturma, D., "Politics and the New Mythology: The Turn to Late Romanticism" u The Cambridge Companion to German Idealism (priredio K. Ameriks), Cambridge University Press, New York 2005., 219-238.

15 Kim, S. H., Max Weber's Politics of Civil Society, Cambridge University Press, West Nyack 2004.

16 Weber, M., "The Meaning of "Ethical Neutrality" u The Methodology of the Social Science (priredili E. Shils \& H. Finch), Free Press, New York 1949., str. 35. 
zupčanik“" velikog i nezaustavljivog mehanizma koji je sam stvorio. U raščaranom svetu likvidirani su mit, misterija i magija, a trijumfovala je sekularna nauka. Naučno-tehnički model proračunatog saznavanja se proširio i na ekonomiju, politiku, pravo, umetnost: kao što je nauka ovladala prirodom putem razuma, tako je moderni industrijski kapitalizam, sledeći profit, organizovao rad i proizvodnju na metodičan i sračunat, efikasan i predvidljiv način, ne obazirući se na tradiciju i osećanja ili ih koristeći za vlastiti pogon; tako je i politički život modernizovan racionalnim ustavom, koji sprovodi obučena administracija prema nemilosrdnim regulama; tako je i pravda sada utemeljena na racionalno formulisanom pravu i depersonalizovana, a njena distribucija funkcionalizovana i mehanizovana; tako su čak i muzika, harmonski i orkestarski, a slikarstvo linearno i perspektivistički, racionalno organizovani i sistematizovani. ${ }^{17}$

Racionalizacija sveta, nužan uslov da se ovlada njime, neizbežno je tako dovela do hegemonije „svrhovite racionalnosti“ (Zweckrationalität), jedne praktične svesti koja, ne dovodeći ciljeve u pitanje, postupa samo s obzirom na procenu uspešnosti sredstava za njihovo ostvarivanje, i istiskivanja ,vrednosne racionalnosti“ (Wertrationalität), koja racionalnost postupaka meri saglasnošću sa određenim uverenjima - „nezavisno od mogućnosti uspeha“.18 Kapitalizam i birokratija, kao „dve najsnažnije i najvažnije manifestacije instrumentalne racionalnosti u moderni“, proizveli su najzad „okove ropstva“ koji moderne ljude čine „,isto toliko nemoćnim kao što su to bili felasi drevnog Egipta“. Smeštenima u taj „gvozdeni kavez“, „pred nama ne leži letnje cvetanje već radije polarna noć ledenog mraka" ${ }^{19}$ Strogo strukturiranje i organizacija vladaju svuda, a iz racionalizovanog i jednoobraznog života iščezava i duhovnost i duševnost: osećanje, spontanost, strast, sloboda, čovečnost, individualna autonomija, sve „nepomireno“ što predstavlja prepreku jasnom i bezdušnom mišljenju i produktivnoj efikasnosti kapitalizma. ${ }^{20}$

17 Veber, M., „Racionalizam zapadne kutlure“ u Sociologija Maksa Vebera (priredio M. Đurić), Naprijed, Zagreb 1987., str. 291-293.

18 Weber, M., "The Social Psychology of the World Religions" u From Max Weber: Essays in Sociology (priredili H. H. Gerth \& C. W. Mills), Oxford University Press, New York 1946., str. 293.

19 Veber, M., Privreda i društvo, tom 1, Prosveta, Beograd 1976.

20 „Strašno je i pomisliti“, priznaje Veber, „kako svet jednog dana neće biti ispunjen ničim drugim već samo onim malim zupcima, malim ljudima koji se drže svojih malih poslova i upinju se da dobiju veće. Svet je u takvoj evoluciji da smo mi već uhvaćeni, a veliko pitanje, prema tome, nije kako da ga unapredimo i ubrzamo, već kako možemo da se suprotstavimo toj mašineriji da bismo sačuvali jedan deo čovečanstva od ovog rasparčavanja duša, od ovog vrhunskog prevladavanja birokratskog načina života“" (prema Nisbet, R., The Social Philosophers, Crowell, New York, 1973., str. 441). 
S Drugim svetskim ratom bezdušnost je dobila dotad nezamislive razmere, a nalog produktivnosti je industrijalizovao čak i smrt. Na njegovom kraju Horkhajmer (Horkheimer) i Adorno (Adorno) pišu svoju Dijalektiku prosvetiteljstva i nalaze da se prosvetiteljski pokret koji je težio emancipaciji uma od okova mita okrenuo, snagom unutrašnje logike, u vlastitu suprotnost: stvorio je pogubne ideologije, izazvao opštu destrukciju smisla, varvarizaciju nauke i umetnosti i sve veće porobljavanje čoveka. Ta ,aporija samouništenja prosvetiteljstva" ukazuje da se u samom pojmu ovog mišljenja, a ne tek u njegovim konkretnim nacionalističkim, paganskim i manifestacijama drugih „modernih mitologija“, nalaze „nazadni momenti“. Umesto da to reflektuje, prosvetiteljstvo je „razorilo i poslednji ostatak vlastite samosvesti“, „ukrutilo se u strahu pred istinom“, zaslepelo se za „destruktivnost napretka“ $\mathrm{i}$ - prepustivši neprijateljima refleksiju o tome - našlo se u situaciji da njegova sudbina može biti zapečaćena. ${ }^{21}$

Horkhajmer i Adorno i dalje ne sumnjaju u to da se sloboda u društvu ne može odvojiti od prosvećenog mišljenja, ali su uvereni da prosvetiteljstvo sada mora da odigra svoju igru još jednom na samom sebi, da se još jednom odvije preko osvešćivanja sebe kao „poslednjeg mita“. Antropomorfizam, projekcija subjektivnog na prirodu, reductio ad hominem reakcija, koja se, prema autorima Dijalektike prosvetiteljstva, nalazi u temelju mitskog straha od nepoznatog, fundira u jednakoj ili u još većoj meri i čitav proces prosvetiteljstva koji je, prema sada samo autoru Negativne dijalektike, tu figuru detektovao i uvek iznova zaboravljao da primeni na sebe, kao svojevrsno vlastito demitologizovanje, kao dosledno ili kao „drugo“ prosvećivanje, kao reductio hominis koje bi konačno svrglo „u apsolut stilizovanog subjekta“.22 U paradoksalnoj situaciji u kojoj se našlo po pređenom putu od varvarstva do novog varvarstva, jedno samoprosvećeno prosvetiteljstvo mora, dakle, da ostane u figuri prosvećenosti, ali i da za volju „određene negacije“ istovremeno utrne svoje fatalne pozitivne programe gospodarenja $\mathrm{i}, \mathrm{u}$ duhu nepopustljive teorije vršeći ,nasilje nad samim sobom“ - „probije granice prosvetiteljstva“". ${ }^{23}$

Takva rekonceptualizacija prosvetiteljstva bi, međutim, morala biti sasvim različita od one koja je zamenila slobodu „pogonom samoodržanja“, morala bi da ga reinstalira tako da se „promišljanjem prirode u subjektu

21 Horkheimer, M. \& T. Adorno, Dialektik der Aufklärung, T. W. Adorno: Gesammelte Schriften, tom 3, Suhrkamp, Frankfurt am Main 1997., str. 11, 19.

22 Adorno, T., Negative Dialektik u T. W. Adorno: Gesammelte Schriften, tom 6, Suhrkamp, Frankfurt am Main 1997, str. 187.

23 Horkheimer, M. \& T. Adorno, str. 12, 57, 19, 234. 
suprotstavlja gospodarenju uopšte“, da postaje jedno „nesputano mišljenje koje se oslobađa vlasti prirode time što priznaje da je njeno vlastito drhtanje pred samom sobom". ${ }^{24}$ To samoprosvećeno prosvetiteljstvo bi tek moglo znati za nešto što je, sudeći po naslovu jednog „Zapisa“ iz Dijalektike prosvetiteljstva, slutio već Volter (Voltaire): da ,predmet teorije nije dobro nego zlo“, da je „sloboda njen element, a tlačenje njena tema“, da „dobrota moći sija jedino u čvrstini misli protiv moći“, da je svaki apologetski jezik već korumpiran, da „postoji samo jedan izraz za istinu: misao koja poriče nepravdu“, kao i da je svako „prizivanje sunca idolopoklonstvo“ a da „tek u pogledu na drvo opaljeno njegovom moći živi slutnja o veličanstvenosti dana koji ne mora ujedno da spaljuje svet koji obasjava“..25 Tek „negativna mudrost“ tako „resetovanog“ prosvetiteljstva zaprečila bi mu vezu sa onim drugim suncem, ,suncem kalkulišućeg uma“ koje „osvetljava tamno obzorje mita i svojim ledenim zracima gaji senke novog varvarstva" ${ }^{26}$ i uz rizik da bude optuženo za kulturni pesimizam ili gnostičku eshatologiju, ${ }^{27}$ odbilo bi $\mathrm{da}$, ,poput racionalističkih filozofija istorije, propisuje neku određenu praksu kao spasonosnu“. 28

\section{DRUGA RUNDA: PROTIV REŽIMA DOMINACIJE}

Ako je za Adorna i Horkhajmera paradigma objektivišućeg, sistematizujućeg i totalizujućeg uma bila prirodna nauka, Fukoova (Foucault) ,,arheologija humanističkih nauka" pokazuje kako ni nauke o čoveku nisu izuzete iz nje. ${ }^{29}$ Ako je kod autora Dijalektike prosvetiteljstva subjekt „temporalni korelat" instrumentalnog uma, ${ }^{30}$ kod autora Arheologije znanja je on, slično, rasuti i diskontinuirani proizvod antropocentričke forme znanja modernog diskursa. ${ }^{31}$ Brižljivim „,arheološkim“ radom na njegovoj „diskurzivnoj kon-

24 Isto, str. 56-58.

25 Isto, str. $247-248$.

26 Isto, str. 49.

27 Videti, na primer, Kuenzli, A., Aufklärung und Dialektik. Politische Philosophie von Hobbes bis Adorno, Rombach, Freiburg 1971., str. 137; Theunissen, M., „Negativität bei Adorno“ u Adorno-Konferenz (priredili L. v. Friedeburg \& J. Habermas), Suhrkamp, Frankfurt am Main 1983., str. 54-55.

28 Horkheimer, M. \& T. Adorno, str. 255.

29 Fuko, M., Riječi i stvari: arheologija humanističkih nauka, Nolit, Beograd 1971., str. 383-425.

30 Velmer, A., Prilog dijalektici moderne i postmoderne: kritika uma posle Adorna, Bratstvo-Jedinstvo, Novi Sad 1987, str. 74.

31 Fuko, M., Arheologija znanja, Plato. Beograd 1998., str. 60. 
strukciji“ otkriva se nezasita „volja za znanjem“ kao simptom njegove zavere sa moći i frustracija zbog nikad do kraja dohvaćene istine kao indikator namera novovekovne saznajne konkviste. ${ }^{32}$ Anonimnu moć, „vlast“ inherentnu proizvodnji istine koja omogućuje disciplinovanje putem diskurzivnih režima nauke, Fuko vidi, takođe poput kritičke teorije, ne kao da je koncentrisana u rukama jedne ustanove, strukture ili obdarenog pojedinca, već raspršenu širom „društva diskursa“, svuda prisutnu, u smislu da „odasvud dolazi“, da je izraz „složene strateške situacije u datom društvu“. ${ }^{33}$ Najzad, racionalizacija i birokratizacija društva, i kod Fukoa su manifestacije uma koji, makar od doba prosvetiteljstva, samoustanovljenjem konstruiše ono „nenormalno“ i proganja u ludilo ili zločin ono što odstupa. ${ }^{34}$ Generaciju iza Frankfurtovaca, Fuko se usredsređuje na rođenje i razvoj disciplinujućih institucija - vaspitnih, kaznenih, zdravstvenih, ustanova socijalne zaštite - pokazujući „dvostruko kretanje oslobođenja i porobljavanja“ i još pedantnije otkrivajući autoritarne tendencije u srcu prosvećenih intencija liberalne moderne. ${ }^{35}$ Ukoliko uopšte figuriše, prosvetiteljstvo je ovde doba „klasicizma“ koje je popločalo put za „,nauke o čoveku“, nauke disciplinovanja, normalizovanja i nadziranja tela i duša, marginalizacije i isključivanja devijantnog, abnormalnog, ludog. U svakom slučaju, razotkrivajući i kritikujući takvu pretenziju u svakoj formaciji moderne koju je tematizovao, činilo se da Fuko napada upravo nasleđe prosvetiteljstva. ${ }^{36}$

32 Uporediti Williams, C., Contemporary French Philosophy: Modernity and the Persistence of the Subject, Athlone, London 2001. Str. 152-254.

33 Fuko, M., Istorija seksualnosti. Volja za znanjem, Prosveta, Beograd 1982., str. 83.

34 Fuko, M., Istorija ludila u doba klasicizma, Nolit, Beograd 1980.; Fuko, M., Nenormalni, Svetovi. Novi Sad 2002.

35 Fuko, M., Nadzirati i kažnjavati: rođenje zatvora, Prosveta, Beograd 1997. Uporediti Ransom, J., Foucault's Discipline: The Politics of Subjectivity, Duke University Press, Durham 1997., str. 11-77; Dinges, M., „The Reception of Michel Foucault's Ideas on Social Discipline, Mental Asylums, Hospitals and The Medical Profession in German Historiography“ $\mathrm{u}$ Reassessing Foucault: Power Medicine and the Body (priredio Roy Porter, Routledge, Florence 1998, str. 181-212; Olssen, M., Michel Foucault: Materialism \& Education, Greenwood, Westport 1999.; Chan, A., Toward a Genealogy of Organizational Culture. The perspectives of Foucault, John Benjamins, Philadelphia 2001., str. 41-56, 89-129; Deacon, R, Fabricating Foucault: Rationalising the Management of Individuals, Marquette University Press, Milwaukee 2003; Dinges 1998.

36 Videti Rajchman, J., Michel Foucault: The Freedom of Philosophy, Columbia University Press, New York 1985., str, 59; Ferry, L, \& A, Renaut, French Philosophy of the Sixties: An Essay on Antihumanism, The University of Massachusetts Press, Amherst 1990., str. 68-120; Passerin d'Entrèves, M., "Michel Foucault on 'Was ist Aufklärung?" u Enlightenment and Modernity (priredio N. Geras), Palgrave, New York 1999, str. 184-185. 
A onda, 1984, na izvestan način svodeći račune, on odgovara na pitanje „šta je prosvećenost“" analizom Kantovog (Kant) istoimenog teksta iz 1784. godine. ${ }^{37}$ Taj tekst Fuko smatra suštinski značajnim za samu ideju moderne, u čije bi nastavljače a ne samo kritičare - ili nastavljače upravo kao kritičare - sada i sebe da ubroji. ${ }^{38}$ Štaviše, Fuko se ne libi da kaže upravo ono što se od njega kao nemilosrdnog kritičara formacija diskurzivnog i faktičkog nasilja moderne ne očekuje ili mu se čak osporava pravo da neprotivrečno tvrdi:39 „kritički posao i danas još implicira veru u prosvetiteljstvo“, što će ovde reći, jedan zahtevan „rad na našim granicama, to jest strastven napor koji daje oblik čežnji za slobodom“.40 Da bi se taj rad, naime, uopšte obavljao, neophodno je držati se ,principa koji je u srcu istorijske svesti, koju je Aufklärung imao sam po sebi“: ,principa kritike i stalnog stvaranja nas samih u našoj samostalnosti““. Jer tek kritički „rad što ga mi sami obavljamo nad nama samima kao slobodna bića“, ukoliko je prožet etosom filozofske

37 Prosvećenost Kant tamo određuje kao „,̌ovekov izlazak iz samoskrivljene nezrelosti“. Nezrelost je „,nemoć da se svojim razumom služimo bez vođstva nekog drugog“, a ona je „samoskrivljena ukoliko njen uzrok ne leži u nedostatku razuma, nego u pomanjkanju odlučnosti i hrabrosti“ da se njime samostalno služimo (Kant, I., „Beantwortung der Frage: Was ist Aufklärung?“ u Kants gesammelten Schriften, tom 8, Walter de Gruyter, Berlin 1968, str. 35).

38 „Kada je 1784. godine Kant pitao Was heisst Aufklärung?, mislio je: Šta se upravo sada zbiva? Šta nam se dešava? Kakav je to svet, kakvo razdoblje, upravo ovaj trenutak u kojem živimo? Ili drugim rečima: Šta smo mi? kao Aufklärer, kao deo prosvetiteljstva? Uporedite to sa kartezijanskim pitanjem: Ko sam ja? Ja kao jedinstveni ali univerzalni i neistorijski subjekt? Za Dekarta je Ja bilo ko, bilo gde u bilo kom trenutku. Ali Kant postavlja jedno drugo pitanje: Šta smo mi? u vrlo preciznom trenutku istorije. Kantovo pitanje se javlja kao analiza i nas i naše sadašnjosti“" (Foucault, M., "The Subject and Power" u Michel Foucault: Beyond Structuralism and Hermeneutics (priredili H. Dreyfus \& P. Rabinow), University of Chicago Press, Chicago 1983., str. 216).

39 Na primer, Habermas, J., „Strelom u srce sadašnjice: uz Fukoovo predavanje o Kantovom tekstu 'Šta je prosvećenost?'“ u Imanuel Kant, Mišel Fuko, Jirgen Habermas, O prosvećenosti, Zavod za kulturu Vojvodine, Novi Sad 2004., str. 37; Bernstein, R., „Foucault: Critique as a Philosophic Ethos" u Critique and Power: Recasting the Foucault/Habermas Debate (priredio M. Kelly), MIT Press, Cambridge 1994, str. 222, 227; Bernstein, R., The New Constellation: The Ethical-Political Horizons of Modernity/Postmodernity, Polity Pres, Cambridge 1991, str. 161; McCarthy, T., "The Critique of Impure Reason: Foucault and the Frankfurt School" u Critique and Power: Recasting the Foucault/Habermas Debate (priredio M. Kelly), MIT Press, Cambridge 1994., str. 259, 272; uporediti i Schmidt, J. \& T. Wartenberg, "Foucault's Enlightenment: Critique, Revolution, and the Fashioning of the Self" u Critique and Power: Recasting the Foucault/Habermas Debate (priredio M. Kelly), MIT Press, Cambridge 1994., str. 283-314; Harpham, G., "So... What Is Enlightenment? An Inquisition into Modernity", Critical Inquiry 20 (3/1994), str. 524-556; Passerin d'Entrèves, M., "Michel Foucault on 'Was ist Aufklärung?'”, str. 185-186.

40 Fuko, M., „Šta je prosvetiteljstvo?“, Treći program 102 (II/1995), str. 240. 
prosvećenosti, ima karakter onog ,istorijsko praktičnog iskušavanja granica koje možemo da prekoračimo". ${ }^{4}$

Ovde ipak počinje izvesno, ne doduše sasvim nedosledno ili antikantovsko, odstupanje od Kanta. Ako istrajnost u kritici onog što govorimo, mislimo i činimo zapravo jeste filozofski „stav-granica“, danas bi tu kritiku, prema Fukoovom mišljenju, trebalo transformisati u praktičnu kritiku ne nužnog nego mogućeg ograničenja, $u$ istorijsko istraživanje kroz događaje koji su nas doveli do toga da se uspostavimo i raspoznamo kao subjekti onoga što činimo, mislimo i govorimo. Ta kritika prestaje da bude transcendentalna i postaje ,arheološka“: ona „neće tražiti izdvajanje univerzalnih struktura čitavog saznanja, ili svake moguće moralne akcije; već, ispitivanje diskursa koji artikuliše šta mislimo, govorimo i činimo“. Njoj neće biti cilj da omogući metafiziku kao nauku već da izloži „,genealogiju“, štaviše da „ponovo pokrene, što je duže i šire moguće, nedefinisani rad slobode“; ona „neće dedukovati iz onog što jesmo ono što nam je nemoguće činiti ili saznati; nego će osloboditi iz slučajnosti, koja je od nas učinila da budemo to što jesmo, mogućnost da više ne budemo to što jesmo, ne činimo ono što činimo, ili ne mislimo ono što mislimo“.42 Dobrovoljna apstinencija od konteksta ukupnosti, totaliteta, zajedničkog značenja, pomirenja, hermeneutike globalnog smisla, transcendentalizma utemeljujućeg subjekta, velikih kauzaliteta i sinteza, epohalnih principa, napredaka, evolucija, za volju strukturalnog opisa - to je ono što brižljivi arheolog postiže svojim iskopavanjima. Genealog će potom, oslonjen na analizu odnosa moći i svestan konstitutivnosti određene diskurzivne prakse, neopterećeno demistifikovati „poreklo“ fenomena. Dijahroniju smenjuje sinhronija mnoštva „diskurzivnih formacija“, a filozofiju istorije majstora mislilaca $\mathrm{i}$ istoričara kritička istorija genealoga koja više neće sa

41 Isto. Uporediti Hoy, D., Critical Resistance: From Poststructuralism to Post-Critique, MIT Press, Cambridge 2004., str. 57-100; Nehamas, A., The Art of Living: Socratic Reflections from Plato to Foucault, University of California Press, Berkeley 1998., str. 172-178. U predavanju iz maja 1978. godine „Šta je kritika?“, Fuko je u još većoj meri naglasio „kritički stav kao vrlinu uopšte“ (Foucault, M., "What is Critique?" u What is Enlightenment? Eighteenth-Century Answers and Twentieth-Century Questions (priredio J. Schmidt), University of California Press, Berkeley 1996., str. 383, 382): „Kritika bi bila veština voljne neposlušnosti, refleksivne nepokornosti. Njena funkcija je desubjektivacija u igri koja bi se mogla nazvati politikom istine“ (Isto, str. 386). Fuko nalazi da ova definicija „nije predaleko“ od znamenite Kantove definicije prosvećenosti iz 1784. godine, koja preko stanja nezrelosti, preko izvesne umne nesposobnosti koja iz toga proizilazi, gotovo ,propovednički“ poziva na hrabost da se odraste i da se koristi vlastiti um: „Kantov opis Aufklärunga zapravo odgovara mom pokušaju da opišem kritiku, onaj kritički stav za koji verujem da se kao specifični stav na Zapadu pojavio sa velikim istorijskim procesom upravljanja društvom“ (Isto, str. 386-387).

42 Fuko, M., „Šta je prosvetiteljstvo?“', str. 241. 
„,nadistorijskog gledišta“ da bude ,istorija čiji bi posao bio da prikupi, u totalitetu potpuno zatvorenom u sebe, najzad svedenu raznolikost vremena; istorija koja bi nam omogućila da se prepoznamo svuda i da svim prošlim pomeranjima damo izgled izmirenja; istorija koja bi na ono što je iza nje bacila pogled s kraja sveta“: „obožavanje spomenika postaje parodija; poštovanje starih kontinuiteta postaje sistematsko razlaganje; kritika nepravdi prošlosti putem istine koju čovek poseduje danas postaje destrukcija subjekta saznanja putem nepravde svojstvene volji za znanjem" ".43 Još ničeanskije i artističkije, neprestano imajući u vidu Kanta, Fuko na kraju „estetiku egzistencije“ nastoji da opremi ne univerzalističkom normativnom etikom i politikom, već razabiranjem i kritikom one istorijske situacije koja sada potrebuje „filozofiju koja ne bi određivala uslove i granice saznanja objekta, već uslove i neodređene mogućnosti preobražaja subjekta“. 44

Budući da su subjekti „fabrikovani“ dominacijom, kritika je osporavanje tako formiranog subjekta, de-formacija, raz-rešenje subjekta (désassujettissement). Ona je „desubjektivacija“ one subjektivnosti koju su inicijalno proizveli odnosi asimetrične moći, dakle, pre svega, negativna rabota rastakanja tog doznačenog i impregniranog osećaja ko smo i šta je ispravno da činimo. Onog „pozitivnog“ i „konstruktivnog“ elementa kritike se radije, prema Fukoovom mišljenju, treba čuvati. Umesto da se u njoj pronađe savet ili uputstvo koje bi kazalo „šta da se radi“, „Fukoova kritika“ upravo hoće da „ishoduje time da se 'više ne zna šta da se radi', da nestanu postupci, gestovi, diskursi koji su do tada bili živi““:45, "Kritika ne mora da bude premisa dedukcije koja se zaključuje konkluzijom 'ovo ili ono treba da bude učinjeno'. Ona treba da bude instrument za one koji se bore, za one koji se opiru i odbijaju ono što jeste. Ona se upotrebljava u procesima konflikata i konfrontacija, ona je esej u odbijanju“ ".6 Lišena direktiva, kritika se podiže protiv ograničenja i osporava, rastapa i neutrališe ona temeljna pozadinska uverenja koja ne dozvoljavaju drugačije uvide i drugačija iskustva. Time ona

43 Fuko, M., „Niče, genealogija, istorija“, Gradac 152-153, 2004, str. 60, 66; uporediti Scott, W., "Reading/Writing/Killing: Foucault, Cultural History and the French Revolution" u Cultural History After Foucault (priredio J. Neubauer), Aldine de Gruyter, New York 1999, str. 133-159.

44 Fuko, M., Hermeneutika subjekta, Svetovi, Novi Sad 2003, str. 649; uporediti Simons, J., Foucault and the Political, Routledge, London 1995, str. 51-104; Meranze, M., "Critique and Government: Michel Foucault and the Question 'What Is Enlightenment?'” u What's Left of Enlightenment?: A Postmodern Question (priredili K. Baker \& P. Reill), Stanford University Press, Stanford 2001., str. 102-114.

45 Foucault, M., "Questions of Method" u Power: Essential Works of Foucault, 1954-1984, tom 3, (priredio J. Faubion), Penguin, London 2002, str. 235.

46 Isto, 236. 
upravo otvara i oblikuje utuljene mogućnosti u pogledu toga ko smo i šta možemo da uradimo sa sobom ne bismo li, u krajnjoj liniji, kreirali sebe kao „delo umetnosti“..47

\section{TREĆA RUNDA: OSVETA $D R U G O G$}

Razlog što se u međuvremenu nije postalo zrelim savremeno mišljenje prosvetiteljstva ne pronalazi u nedoslednom praktikovanju uputstava prosvetitelja ili u nesalomivosti otpora protivprosvetiteljskih snaga, već upravo $\mathrm{u}$ manjku samoprosvećenosti prosvetiteljstva, u izostanku autoreferentne korekcije s obzirom na ,primedbu romantizma“, u neobračunavanju troškova ogrešenja o ono „drugo“ prosvećenosti, koje je nereflektovano potkopavalo njegov kritički program. Ako se taj manjak shvati kao strukturalni i neprebrodiv hendikep, samoprosvećivanje prosvetiteljstva se pretvara u oproštaj s njim. Poput Horkhajmera i Adorna koji su imali u vidu, uglavnom, ,prirodu“, poput Fukoa, s ovakvim ili onakvim „zatvorenicima“ na umu, Hartmut (Hartmut) i Gernot (Gernot) Beme (Böhme) nalaze drugo ime za ono što je prosvećenost odgurnula $u$,nezrelost“, ne bi li na taj način razobličili gospodarsku isključivost autonomne, punopravne ,zrelosti“ kao uzora prosvetiteljstva. Kao što je podjarmilo i potisnulo prirodu i uklonilo ludake sa položaja u društvu, prosvetiteljstvo je naime isto tako ,izgnalo i fantaziju iz filozofije“. Upravo sa Kantom je, prema ovom tumačenju, osporeno ikakvo mesto mašte među moćima saznanja, u koje je dotad vazda ubrajana. ${ }^{48}$

Sve ono što je ustajalo u ime fantazije, osećanja i pobožnosti, kao i u ime neposrednosti i prirodnosti, bio je za prosvetitelje osamnaestog veka staro, mračno i zastarelo, anahroni duhovi prošlosti na čiju pojavu su uvek iznova reagovali žestoko. ${ }^{49}$ Ta reakcija bi sada trebalo da bude prokazujuće svedočanstvo zaslepljenosti i, istovremeno i važnije, reaktivne zavisnosti prosvetiteljstva: samo njegovo određenje po prvi put postaje eksplicitno tek u pokušaju da se odbrani od fantasta. Retrospektivni pogled braće Beme maštu,

47 Foucault, M., "On the Genealogy of Ethics: An Overview of Work in Progress" u Ethics: Subjectivity and Truth (priredio P. Rabinow), The New Press, New York 1997. str. 261.

48 Böhme, H. \& G. Böhme, "The Battle of Reason with the Imagination" u What Is Enlightenment? Eighteenth-Century Answers and Twentieth-Century Questions (priredio J. Schmidt), University of California Press, Berkeley 1996., str. 426; uporediti Promies, W., Der Bürger und der Narr oder das Risiko der Phantasie. Sechs Kapitel über das Irrationale in der Literatur des Rationalismus, Hanser, München 1966; Engell, J., The Creative Imagination: Enlightenment to Romanticism, Harvard University Press, Cambridge 1981.

49 Böhme, H. \& G. Böhme, "The Battle of Reason with the Imagination", str. 434. 
kao negativni oslonac, odredbenog neprijatelja, instalira u konstitutuent prosvetiteljstva koje se klelo u samozakonodavstvo: prosvetitelji i fantasti, kao njihovi „neprijatni drugi“, vezani su jedni za druge i smenjuju se u uzajamnoj prozivci zbog ponovnog izlaska na scenu. „Racionalizam i iracionalizam određuju jedno drugo, a ipak je ovaj odnos još uvek asimetričan. Razum određuje sebe - to je program kritičke filozofije - ali je Drugo samo Drugo. Ono je iracionalno; maglovita smeša koja se u najboljem slučaju svodila u polemici na jedan zajednički imenilac: maštu“". 50

Svaka definicija prosvetiteljstva svedoči o zastrašenom odgovoru na tu preteću „drugost“, a samo prosvetiteljstvo se u tom smislu pojavljuje „,doslovno kao dijetetika razuma, kao veliko terapeutsko postignuće“. ${ }^{51}$ Um koji (bi da) gospodari proizvodi vlastiti otpor i brižljivo trebi umno od bezumnog u teoriji. On izoluje sferu koja ne spada u okvire razumnog izricanja, a telo, osećanja, „metafizičke potrebe“, potrebe za neposrednošću, život i prirodu proganja u iracionalno i doslovno „ludo“, pripisujući mu „budalaste ili haotične crte“. To ne može da prođe bez posledica i po sam um, od kojih se svojevrsni autizam ne čini najmanjom. Sve od njega različito postaje opasno, a ukoliko se uopšte odluči da mu pristupi, kompulzivni gest može biti jedino nasilje. „Um se povukao u sebe i na taj način povukao od Drugog. Saobraćaj izvan granica utvrđenja je postao težak. Drugo je postalo strano i neshvatljivo".52

Uzima se da je postmodernizam u svom glavnom toku otprilike ovako reagovao na odmakli udes prosvećenosti, te da je deo njegove uobičajene mantre objava ne neophodnosti njegove korekcije nego „sumraka“. Doduše, među njegovim vodećim filozofskim protagonistima teško je naći jevanđeliste apokalipse prosvetiteljstva - ako se izuzme Liotar (Lyotard), koji je verovatno i najodgovorniji za sliku postmodernizma kao protivprosvetiteljstva. U Postmodernom stanju on prosvećenost, „u kojoj junak znanja deluje u dobrom etičko-političkom cilju univerzalnog mira“, shvata kao primer filozofskog legitimacijskog metadiskursa, primer velike „moderne“ naracije koja implicira jednu filozofiju istorije, metanaracije koja legitimizuje ujedno i znanje i društvene institucije i za koju je karakteristično da će se „pravilo konsenzusa između onog koji upućuje i onog kome je upućen neki iskaz s vrednošću istine smatrati prihvatljivim ako je ucrtan u perspektivu moguće

50 Isto, str. 435.

51 Schings, H.-J., Melancholie und Aufklärung. Melancholiker und ihre Kritiker in Erfahrungsseelenkunde und Literatur des 18. Jahrhunderts, Metzler, Stuttgart 1977., str. 195;

Böhme, H. \& G. Böhme, ,The Battle of Reason with the Imagination“, str. 436.

52 Böhme, H. \& G. Böhme, "The Battle of Reason with the Imagination”, str. 437. 
saglasnosti razumnih duhova“. Postmoderna, kao ishod velikog modernog „pokreta de-legitimizacije“, onda bi bila, u izrazu za koji Liotar priznaje da je uprošćen, „nepoverenje prema metanaracijama“. ${ }^{53}$ Svaka „velika priča izgubila je verodostojnost, ma kakav joj način ujedinjavanja bio pridavan: i kao spekulativna priča i kao priča o emancipaciji“" ${ }^{54}$

U Hegelovom sistemu filozofije je tako sve znanje dovedeno u odnos, a ono istinsko znanje sastavljeno od izveštaja o njima koji su inkorporirani u ,veliku priču“ o subjektu koji, prema svojim pravilima, prosuđuje i jemči njihovu legitimnost. „Delegitimisano“ postmoderno znanje sada, međutim, zna da „nauka igra sopstvenu igru koja ne može da legitimizuje druge jezičke igre“. Ono bi sada, bez nostalgije, bez iluzije mogućeg pomirenja između jezičkih igara, bez čežnje za celinom i jedinstvom, da signalizira uzmak univerzalnog metajezika i sistemskih projekata. Ono bi da favorizuje „male priče“, rascepkanost, disenzus, neslaganje, agonistiku jezičkih postupaka, borbu u smislu nesvodive pluralnosti jezičkih igara, da ,izoštrava našu osetljivost za razlike i jača našu sposobnost da podnosimo nemerljivo“. Ono ne bi da traži „opravdanje u homologiji stručnjaka“, već da se „legitimizuje putem paralogije izumitelja“, da vrati naraciju ,u diskurse legitimizovanja kao što su: otvorena sistematika, lokalnost, antimetod".55 Postmoderno znanje se tako suprotstavlja „volji za istinom koja vulgarizuje sve jezike“ i nuka filozofiju da napusti teorijski žanr: da, kao ,pseudoteorija“ ili „,teorija-fikcija“, parodira teoriju, da uznemirava njen gospodarski diskurs razlikovanja i regulisanja istinitog i lažnog, umesto da ga reprodukuje, i uvede i u svoj diskurs ,istu istančanost, istu snagu lakoće koja sebi daje maha u delima slikarstva, muzike, takozvanog eksperimentalnog filma, a očigledno i u naučnim delima“. .56

U drugom tipu modernog metanarativa, velikoj priči o emancipaciji, znanje nije cilj po sebi, već se vrednuje s obzirom na ljudsku slobodu. Liotar smatra da je u filozofiji prosvetiteljstva začeta ideja emancipacije čovečanstva, da njen pogon nastupa sa Francuskom revolucijom, da bi u devetnaestom i dvadesetom veku, kroz prosvetiteljsku viziju obrazovanja kao sredstva oslobađanja građana iz okova neslobode, ,upravljao mišljenjem i akcijom“. Uverenje je da će nesumnjivi progres nauke, tehnike, umetnosti i narastajuće političke slobode osloboditi i ,čitavo čovečanstvo od neznanja,

53 Liotar, Ž.-F., Postmoderno stanje, Bratstvo-Jedinstvo, Novi Sad 1988, str. 5-6.

54 Isto, str. 62.

55 Liotar, Ž.-F., Postmoderno stanje, str. 66, 67, 21, 98, 7, 99; uporediti Lyotard, J.-F. \& J.-L. Thébaud, Just Gaming, Manchester University Press, Manchester 1985., str. 19-43.

56 Liotar, Ž.-F., Postmoderno stanje,str. 62; Liotar, Ž.-F., „Apatija u teoriji“ u Filozofsko čitanje Frojda (priredio O. Savić), IIC SSOS, Beograd 1988., str. 486. 
siromaštva, surovosti, despotizma i ne samo da će ljudi postati srećni nego će, zahvaljujući Školi, postati prosvećeni, postaće gospodari svojih sudbina“. Ta velika priča emancipacije imala je različite vidove - njena prosvetiteljska verzija usredsređuje se na oslobođenje naroda od religioznog praznoverja, a marksistička na oslobođenje radnika od eksploatacije - ali za marksizam, liberalizam, socijalizam, radikalizam, svejedno, „obećanje slobode je horizont progresa i pozakonjenja“, a cilj je emancipacija čovečanstva od dogme, izrabljivanja i patnje. ${ }^{57}$ Aktuelnim političkim prostorom, doduše, i dalje dominira retorika emancipacije, ali teško da ona može da prikrije, a kamoli zaleči „ožiljke koje je moderni ideal zadobio u toku dvesta godina istorije“. Ti ožiljci su svedočanstvo (samo)povređivanja terapijom za koju se mislilo da ih vida, a ne njenog manjka: „Ne odsustvo progresa, nego upravo obrnuto, tehnonaučni, umetnički, ekonomski i politički razvoj omogućili su totalne ratove, totalitarizme, sve veći jaz bogatog Severa i siromašnog Juga, nezaposlenost i novo siromaštvo, sve veću opštu neobrazovanost s krizom škole, kao i izolaciju umetničkih avangardi“ .58

Imperativna sugestija je da se odustane od projekta i od projektovanja, od velikih priča moderne, od naracija koje pozakonjuju sve političke prakse iz nekakve ideje koja čeka ostvarenje, iz budućnosti koja treba da se sluči i kojoj valja da to omogućimo. Ideje poput slobode, svetlosti ili socijalizma mogu imati tu moć jer su univerzalne, jer „usmeravaju sve ljudske realitete“. Sa Aušvicom je, međutim, eksplodiralo ono što su najavljivale ove obećavajuće slike i razotkrilo ih u njihovoj pogubnoj konstrukciji. Priča o iskupljenju Adamovog greha ljubavlju, priča o oslobođenju od neznanja i ropstva kroz saznanje i egalitarizam, spekulativna priča o postvarenju univerzalne ideje kroz dijalektiku stvarnog, marksistička priča o emancipaciji od izrabljivanja i otuđenja podruštvljavanjem rada, kapitalistička priča o emancipaciji od siromaštva industrijskim razvojem, zapravo je jedna priča, jedna istorija, nadahnuta istom obuhvatnom idejom, priča o univerzalnoj slobodi, o oslobađanju čitavog čovečanstva. ${ }^{59}$ Uvek je reč o nasilju univerzalističkih i za stvarnost

57 Lyotard, J.-F., "A Svelte Appendix to the Postmodern Question" u Political Writings, University College London, London 1993., str. 27.

58 Isto, str. 28.

59 Lyotard, J.-F., Postmoderna protumačena djeci, August Cesarec, Zagreb 1990., str. 40. Priča o emancipaciji i spekulativna priča, naime, imaju sličnu strukturu: različite oblasti znanja se okupljaju da bi se u projektovanoj budućnosti našao odgovor na probleme savremenog društva, odnosno sve društvene institucije sjedinjuju se u težnji zajedničkom cilju čitavog čovečanstva, apsolutnom znanju ili univerzalnoj emancipaciji. Sve velike priče, Liotar misli nužno i srećom, dovela je u pitanje transformacija statusa znanja koja se desila u poslednjih pola veka. Znanje više nije organizovano i legitimisano s obzirom na ispunjenje univerzal- 
merodavnih ideja koje moderni daju karakterističan modus projekta: „Moje tumačenje glasi da moderni projekt (projekt realizacije univerzalnosti) nije bio napušten, zaboravljen, nego uništen, 'likvidiran'. Aušvic je“, zaključuje Liotar, ,paradigmatsko ime tragičnog 'nedovršenja' moderne“. .60

\section{REMI U ČETVRTOJ RUNDI: USVAJANJE I PREKONFIGURACIJA}

Rezerve prema odbacivanju prosvetiteljstva jednog od onih koji su promovisani u apostole filozofije postmoderne, Ričarda Rortija (Richard Rorty), sa stanovišta popularne ortodoksije postmodernizma mogle bi izgledati kao sumnjivo baštinjenje, ako ne tradicionalnih vrednosti jednog posustalog projekta, onda zasigurno same ideje emancipatorskog projektovanja. ${ }^{61}$ Ideale prosvetiteljstva on čak naziva „najvrednijim kulturnim nasleđem“, a poimanje da je očuvanje vrednosti prosvetiteljstva jedina nada čovečanstva „potpuno opravdanim“. ${ }^{62}$ Doduše, Rorti predlaže da se razlikuju dva prosvetiteljska projekta koje je, prema njegovom uverenju, uputno strogo odvojiti. Prvi je politički projekt stvaranja „,sveta bez kasta, klasa i okrutnosti. Njega je, tvrdi on, vredno slediti, jer još postoji nada da će „čovečanstvo konačno pobeći od huliganstva školskih dvorišta, otkloniti detinjarije i biti moralno zrelo“.63 Drugi, filozofski projekt, u čiji (samo)kritički potencijal Fuko, kao i

nih ljudskih ciljeva, već se vrednuje s obzirom na njegovu „delotvornost i isplativost na tržištu globalne ekonomije“ (Isto, str. 61; Liotar, Ž.-F., Raskol, Izdavačka knjižarnica Zorana Stojanovića, Sremski Karlovci 1991, str. 169; uporediti Malpas, S., Jean-François Lyotard, Routledge, London 2005., str. 26-28, 73-77).

60 Isto, str. 33.

61 „Neki savremeni intelektualci, posebno u Francuskoj i Nemačkoj, smatraju očiglednim da je holokaust jasno pokazao da su nade u ljudsku slobodu, koje su se javile u devetnaestom veku, zastarele - da pred kraj dvadesetog veka, mi postmodernisti znamo da je projekat Prosvetiteljstva osuđen na propast. Ali, čak i ti intelektualci, u trenucima kada ne pridikuju i ne morališu, čine sve da unaprede taj projekat. Tako i treba da rade, jer niko se još nije pojavio sa boljim projektom“ (Rorti, R., „Ljudska prava, racionalnost i sentimentalnost“, Beogradski krug 3-4, 1-2/1995, 1996, str. 56).

62 Rorty, R., Filozofija i ogledalo prirode, „Veselin Masleša“. Sarajevo 1990., str. 323.

63 Rorty, R., "The Continuity between the Enlightenment and 'Postmodernism"' u What's Left of Enlightenment? A Postmodern Question (priredili K. Baker \& P. Reill, Stanford University Press, Stanford 2001., str.19, 23. O blagonaklonim i manje blagonaklonim interpretacijama Rortijevog „neobičnog prosvetiteljstva“: Garard, G., Protivprosvetiteljstva: od osamnaestog veka do danas, Vidici, Banja Luka 2011., str. 180; naročito s obzirom na njegovu „liberalnu utopiju“ videti Bernstein, R., "Rorty's Inspirational Liberalism” u Richard Rorty (priredili C. Guignon \& D. Hiley), Cambridge University Press, New York 2003., str. 124-138; Elshtain, J., "Don't Be Cruel: Reflections on Rortyian Liberalism" u Richard Rorty (priredili C. Guignon \& D. Hiley), Cambridge University Press, New York 2003, str. 139-157. 
Adorno i Horkhajmer, i dalje polažu jedinu nadu, naprotiv, zaslužuje da propadne, jer je i dalje oslonjen na autoritet „stvarnosti“ koju „objektivno“ može da zahvati i jer odatle pre ili kasnije neminovno smera da „uradi Prirodi, Umu i Istini isto ono što je osamnaesti vek uradio Bogu“". ${ }^{64}$

Rorti bi, drugačije rečeno, da odbaci „racionalizam“ prosvećenosti, a da zadrži njen politički program, odnosno da se založi upravo za jedan ,zreli (descijentizovani, difilozoficirani) liberalizam prosvetiteljstva". ${ }^{65}$ Moralna i politička refleksija liberalizma stoga treba da izmeni rečnik prosvetiteljskog racionalizma, koji se „vrti oko poimanja istine, racionalnosti i moralne obaveze“. Taj rečnik je bio bitan u početku liberalne demokratije, ali je u međuvremenu postao zapreka očuvanju i napretku demokratskih društava - koji bi se lakše ostvario rečnikom koji se ,vrti oko poimanja metafore i samostvaranja“. Umesto nade prosvetiteljstva da se kultura kao celina može „racionalizovati“ i „scijentizovati“, Rorti nalazi da je sada potrebna redeskripcija liberalizma kao nade da se ona može ,poetizovati“. 66

Moglo bi se, naravno, bez ogrešenja reći da je Rorti bliži jednom ranom romantizmu nego (pre)zrelom prosvetiteljstvu, onoj miroljubivoj viziji poetizovanog sveta (,književne kulture“) koju su zastupala prva simpatično, osećajno i talentovano neposlušna deca prosvetiteljstva. ${ }^{67}$ Ali bi makar jednako uverljivo moglo da se tvrdi da je primedba romantizma uvažena a prosvetitljstvo, kadro za autokorekciju, dospelo do svesti o vlastitim deficitima i preoblikovalo jednostranost ili rigidnost vlastite pozicije. Rortijevo nastojanje bi se utoliko moglo odrediti kao napor, unutar makar jedne dimenzije samog prosvetiteljskog nasleđa, da se revitalizuju oni „romantičarski“ momenti koje je pravoverna prosvećenost prepoznavala i karikirala kao pomamu iracionalnosti, a filozofija postmoderne onda takve nagrđene preuzela, usvojila i s pravednošću osvetnika reafirmisala. ${ }^{68}$ Čini se, u svakom slučaju, da prosveti-

64 Isto, str. 19.

65 Rorty, R., Kontingencija, ironija i solidarnost, Naprijed, Zagreb 1995., str. 74.

66 Isto, str. 69.

67 Uporediti Rorti, R., „Propast izbaviteljske istine i uspon književne kulture“, Treći program 123-124 (3-4/2004), str. 139-158; Rorty, R. \& G. Vattimo, The Future of religion (priredio S. Zabal), Columbia University Press, New York 2005., str. 65; Rorty, R., "Pragmatism as Romantic Polytheism" u Philosophy As Cultural Politics, Philosophical Papers, tom 4, Cambridge University Press, New York 2007., str. 27-41; Rorty, R., "Pragmatism and Romanticism" u Philosophy As Cultural Politics, Philosophical Papers, tom 4, Cambridge University Press, New York 2007., str. 105-119.

68 Takvo nastojanje da se utvrdi istorijski kontinuitet prosvetiteljstva i romantizma, sa doduše sasvim drugih polazišta, svedoči i Manfred Frank (Manfred Frank). On brižljivo detektuje i istrajno prati mutaciju ranoromantičarskih motiva u postmodernoj kritici uma i romantičarsku kritiku prosvetiteljstva vidi, na kraju krajeva, kao dosledno prosvetiteljski 
teljstvo ima i istorijski i diskurzivni kapacitet da usvoji „estetičku primedbu“ romantizma. Štaviše, moglo bi se reći da tek pomerajući se ka viziji njenih romantičkih zastupnika, ono na vlastitu polzu postaje kadro da osvesti manjkavosti i zlehude učinke svog programa i napusti ih ili evenutalno koriguje. Ali takvo prosvetiteljstvo više ne bi činilo samo ustupak romantizmu, nego i predstavljalo modus zajedničkog punopravnog preživljavanja.

\section{LITERATURA}

Adorno, T., Negative Dialektik u T. W. Adorno: Gesammelte Schriften, tom 6, Suhrkamp, Frankfurt am Main 1997, str. 7-412.

Beiser, F., "Early Romanticism and the Aufklärung" u What Is Enlightenment? Eighteenth-Century Answers and Twentieth-Century Questions (priredio J. Schmidt), University of California Press, Berkeley 1996., str. 317-329.

Berlin, I., "The Counter-Enlightenment" u Dictionary of the History od Ideas, tom 2 (priredio P. Wiener), Scribner, New York 1973., str. 100-112.

Berlin, I., Koreni romantizma, Službeni glasnik, Beograd 2006.

Bernstein, R., "Foucault: Critique as a Philosophic Ethos" u Critique and Power: Recasting the Foucault/Habermas Debate (priredio M. Kelly), MIT Press, Cambridge 1994, str. 211-241.

Bernstein, R., "Rorty's Inspirational Liberalism" u Richard Rorty (priredili C. Guignon \& D. Hiley), Cambridge University Press, New York 2003., str. 124-138.

Bernstein, R., The New Constellation: The Ethical-Political Horizons of Modernity/ Postmodernity, Polity Pres, Cambridge 1991.

Blake, W., "Laocoön" [1826-1827], http://en.wikisource.org/wiki/Laocoon_(Blake), 12.5.2011.

Böhme, H. \& G. Böhme, "The Battle of Reason with the Imagination" u What Is Enlightenment? Eighteenth-Century Answers and Twentieth-Century Questions (priredio J. Schmidt), University of California Press, Berkeley 1996, str. 426-452.

Bowie, A., From Romanticism to Critical Theory. The Philosophy of German Literary Theory, Routledge, London 1997.

Chan, A., Toward a Genealogy of Organizational Culture. The perspectives of Foucault, John Benjamins, Philadelphia 2001.

negativizam (Frank, M., Conditio moderna, Svetovi, Novi Sad 1995., str. 22: videti Frank, M., Einführung in die frühromantische Ästhetik; Frank, M., The Philosophical Foundations of Early German Romanticism, State University of New York Press, New York 2004, str. 56, 33-34; uporediti Pippin, R., The Persistence of Subjectivity: On the Kantian Aftermath, Cambridge University Press, Cambridge 2005., str. 168-185): romantičarska koliko i prosvetiteljska, tradicija „osporavanja analize u ime sinteze“ od početka primećuje da je esprit d'analyse prosvetiteljstva dogmatski uzurpirao racionalnost, dijalektičkim uopštavanjem postajući ,jedna isto tako pozitivna ideologija kakva je bila ona protiv koje je ustao“ (Frank, M., Conditio moderna, str. 46-47). 
Deacon, R, Fabricating Foucault: Rationalising the Management of Individuals, Marquette University Press, Milwaukee 2003.

Dinges, M., "The Reception of Michel Foucault's Ideas on Social Discipline, Mental Asylums, Hospitals and The Medical Profession in German Historiography" u Reassessing Foucault: Power Medicine and the Body (priredioRoy Porter, Routledge, Florence 1998, str. 181-212.

Elshtain, J., "Don't Be Cruel: Reflections on Rortyian Liberalism" u Richard Rorty (priredili C. Guignon \& D. Hiley), Cambridge University Press, New York 2003, str. 139-157.

Engell, J., The Creative Imagination: Enlightenment to Romanticism, Harvard University Press, Cambridge 1981.

Ferry, L, \& A, Renaut, French Philosophy of the Sixties: An Essay on Antihumanism, The University of Massachusetts Press, Amherst 1990.

Foucault, M., "On the Genealogy of Ethics: An Overview of Work in Progress" u Ethics: Subjectivity and Truth (priredio P. Rabinow), The New Press, New York 1997.str.253-280.

Foucault, M., "Questions of Method" u Power: Essential Works of Foucault, 19541984, tom 3,(priredio J. Faubion), Penguin, London 2002, str. 223-238.

Foucault, M., "The Subject and Power" u Michel Foucault: Beyond Structuralism and Hermeneutics (priredili H. Dreyfus \& P. Rabinow), University of Chicago Press, Chicago 1983., str. 208-226.

Foucault, M., "What is Critique? " u What is Enlightenment? Eighteenth-Century Answers and Twentieth-Century Questions (priredio J. Schmidt), University of California Press, Berkeley 1996., str. 382-398.

Fuko, M., „Niče, genealogija, istorija“, Gradac 152-153, 2004, str. 54-66.

Fuko, M., „Šta je prosvetiteljstvo?“, Treći program 102 (II/1995), str. 232-244.

Fuko, M., Arheologija znanja, Plato. Beograd 1998.

Fuko, M., Hermeneutika subjekta, Svetovi, Novi Sad 2003.

Fuko, M., Istorija ludila u doba klasicizma, Nolit, Beograd 1980.

Fuko, M., Istorija seksualnosti, tom 1: Volja za znanjem, Prosveta, Beograd 1982.

Fuko, M., Nadzirati i kažnjavati: rođenje zatvora, Prosveta, Beograd 1997.

Fuko, M., Nenormalni, Svetovi. Novi Sad 2002.

Fuko, M., Riječi i stvari: arheologija humanističkih nauka, Nolit, Beograd 1971.

Frank, M., Conditio moderna, Svetovi, Novi Sad 1995.

Frank, M., Einführung in die frühromantische Ästhetik, Suhrkamp, Frankfurt am Main 1989.

Frank, M., The Philosophical Foundations of Early German Romanticism, State University of New York Press, New York 2004.

Garard, G., Protivprosvetiteljstva: od osamnaestog veka do danas, Vidici, Banja Luka 2011.

Habermas, J., „Strelom u srce sadašnjice: uz Fukoovo predavanje o Kantovom tekstu 'Šta je prosvećenost?"“ u Imanuel Kant, Mišel Fuko, Jirgen Habermas, $O$ prosvećenosti, Zavod za kulturu Vojvodine, Novi Sad 2004., str. 33-40.

Harpham, G., "So... What Is Enlightenment? An Inquisition into Modernity", Critical Inquiry 20 (3/1994), str. 524-556.

Helderlin, F., „Najstariji sistemski program nemačkog idealizma“‘[1795] u O pesničkoj umetnosti, Rad, Beograd 1997., str. 103-105.

Hit, D. \& D. Boreham, Romantizam za početnike, Hinaki, Beograd 2003. 
Horkheimer, M.\& T. Adorno, Dialektik der Aufklärung, T. W. Adorno: Gesammelte Schriften, tom 3, Suhrkamp, Frankfurt am Main 1997.

Hoy, D., Critical Resistance: From Poststructuralism to Post-Critique, MIT Press, Cambridge 2004.

Janjion, M., Romantizam. Revolucija. Marksizam, Nolit, Beograd 1976.

Kant, I., „Beantwortung der Frage: Was ist Aufklärung?“ u Kants gesammelten Schriften, tom 8, Walter de Gruyter, Berlin 1968 [1784], str. 35-42.

Kim, S. H., Max Weber's Politics of Civil Society, Cambridge University Press, West Nyack 2004.

Kuenzli, A., Aufklärung und Dialektik. Politische Philosophie von Hobbes bis Adorno, Rombach, Freiburg 1971.

Liotar, Ž.-F., „Apatija u teoriji“ u Filozofsko čitanje Frojda (priredio O. Savić), IIC SSOS, Beograd 1988., str. 486-498.

Liotar, Ž.-F., Postmoderno stanje, Bratstvo-Jedinstvo, Novi Sad 1988.

Liotar, Ž.-F., Raskol, Izdavačka knjižarnica Zorana Stojanovića, Sremski Karlovci 1991.

Lyotard, J.-F.\& J.-L. Thébaud, Just Gaming, Manchester University Press, Manchester 1985.

Lyotard, J.-F., “A Svelte Appendix to the Postmodern Question" u Political Writings, University College London, London 1993., str. 25-29.

Lyotard, J.-F., Postmoderna protumačena djeci, August Cesarec, Zagreb 1990.

Lovejoy, A., "Schiller and the Genesis of German Romanticism" u Essays in the History of Ideas, Capricorn Books, New York 1960., str. 207-227.

Lovejoy, A., "The Meaning of 'Romantic' in Early-German Romanticism" u Essays in the History of Ideas, Capricorn Books, New York 1960., str. 183-206.

Malpas, S., Jean-François Lyotard, Routledge, London 2005.

McCarthy, T., "The Critique of Impure Reason: Foucault and the Frankfurt School" u Critique and Power: Recasting the Foucault/Habermas Debate (priredio M. Kelly), MIT Press, Cambridge 1994., str. 243-282.

Meranze, M., "Critique and Government: Michel Foucault and the Question 'What Is Enlightenment?'" u What's Left of Enlightenment?: A Postmodern Question (priredili K. Baker \& P. Reill), Stanford University Press, Stanford 2001., str. 102-114.

Nehamas, A., The Art of Living: Socratic Reflections from Plato to Foucault, University of California Press, Berkeley 1998.

Nisbet, R., The Social Philosophers, Crowell, New York, 1973.

Novalis, „Fragmenti“ u Romantizam (priredio Z. Gluščević), Obod, Cetinje 1967., str. 61-77.

Olssen, M., Michel Foucault: Materialism \& Education, Greenwood, Westport 1999.

Passerin d'Entrèves, M., "Michel Foucault on 'Was ist Aufklärung?"' u Enlightenment and Modernity (priredio N. Geras), Palgrave, New York 1999, str. 184-203.

Peri, M., Intelektualna istorija Evrope, Clio, Beograd 2000.

Pippin, R., The Persistence of Subjectivity: On the Kantian Aftermath, Cambridge University Press, Cambridge 2005.

Promies, W., Der Bürger und der Narr oder das Risiko der Phantasie. Sechs Kapitel über das Irrationale in der Literatur des Rationalismus, Hanser, München 1966.

Rajchman, J., Michel Foucault: The Freedom of Philosophy, Columbia University 
Press, New York 1985.

Ransom, J., Foucault's Discipline: The Politics of Subjectivity, Duke University Press, Durham 1997.

Rorti, R., „Ljudska prava, racionalnost i sentimentalnost“, Beogradski krug 3-4, $1-2 / 1995,1996$, str. 41-58.

Rorti, R., „Propast izbaviteljske istine i uspon književne kulture“, Treći program 123124 (3-4/2004), str. 139-158.

Rorty, R. \& G. Vattimo, The Future of religion (priredio S. Zabal), Columbia University Press, New York 2005.

Rorty, R., "Pragmatism and Romanticism" u Philosophy As Cultural Politics, Philosophical Papers, tom 4, Cambridge University Press, New York 2007., str. $105-119$.

Rorty, R., "Pragmatism as Romantic Polytheism" u Philosophy As Cultural Politics, Philosophical Papers, tom 4, Cambridge University Press, New York 2007., str. 27-41.

Rorty, R., "The Continuity between the Enlightenment and 'Postmodernism' " u What's Left of Enlightenment? A Postmodern Question (priredili K. Baker \& P. Reill, Stanford University Press, Stanford 2001., str. 19-36.

Rorty, R., Filozofija i ogledalo prirode, „Veselin Masleša“. Sarajevo 1990.

Rorty, R., Kontingencija, ironija i solidarnost, Naprijed, Zagreb 1995.

Saul, N., "The Pursuit of the Subject: Literature as Critic and Perfecter of Philosophy 1790-1830" u Philosophy and German Literature, 1700-1990 (priredio N. Saul), Cambridge University Press, West Nyack 2002., str. 57-101.

Schiller, F., "Über naive und sentimentalische Dichtung” [1795-1796], http://www. kuehnle-online.de /literatur/schiller/werke/phil/nsdichtung/, 9.5.2008.

Schiller, F., Ueber die ästhetische Erziehung des Menschen, in einer Reihe von Briefen [1801], http://gutenberg.spiegel.de/buch/3355/, 3.5.2009.

Schings, H.-J.,Melancholie und Aufklärung. Melancholiker und ihre Kritiker in Erfahrungsseelenkunde und Literatur des 18. Jahrhunderts, Metzler, Stuttgart 1977.

Schmidt, J. \& T. Wartenberg, „Foucault's Enlightenment: Critique, Revolution, and the Fashioning of the Self" $\mathrm{u}$ Critique and Power: Recasting the Foucault/ Habermas Debate (priredio M. Kelly), MIT Press, Cambridge 1994., str. 283-314.

Scott, W., "Reading/Writing/Killing: Foucault, Cultural History and the French Revolution" u Cultural History After Foucault (priredio J. Neubauer), Aldine de Gruyter, New York 1999, str. 133-159.

Shelley, P. B., Defence of Poetry [1821], http://rpo.library.utoronto.ca/content/ defence-poetry-part-first-1821, 12.2.2010.

Simons, J., Foucault and the Political, Routledge, London 1995.

Sturma, D., "Politics and the New Mythology: The Turn to Late Romanticism" u The Cambridge Companion to German Idealism (priredio K. Ameriks), Cambridge University Press, New York 2005., 219-238.

Šlegel, F., „Fragmenti Ideje“ u Ironija ljubavi: (izbor iz dela), Zepter Book World, Beograd 1999., str 106-122.

Šlegel, F., „Ironija ljubavi““ u Ironija ljubavi: (izbor iz dela), Zepter Book World, Beograd 1999., str. 142-146.

Theunissen, M., „Negativität bei Adorno“ u Adorno-Konferenz (priredili L. v. 
Friedeburg \& J. Habermas), Suhrkamp, Frankfurt am Main 1983., str. 41-65. Veber, M., „Racionalizam zapadne kulture“ u Sociologija Maksa Vebera (priredio M. Đurić), Naprijed, Zagreb 1987, str. 290-305.

Veber, M., Privreda i društvo, tom 1, Prosveta, Beograd 1976.

Weber, M., "The Meaning of "Ethical Neutrality" u The Methodology of the Social Science (priredili E. Shils \& H. Finch), Free Press, New York 1949., str. $1-47$.

Weber, M., "The Social Psychology of the World Religions" u From Max Weber: Essays in Sociology (priredili H. H. Gerth \& C. W. Mills), Oxford University Press, New York 1946., str.267-301.

Velmer, A., Prilog dijalektici moderne i postmoderne: kritika uma posle Adorna, Bratstvo-Jedinstvo, Novi Sad 1987.

Williams, C., Contemporary French Philosophy: Modernity and the Persistence of the Subject, Athlone, London 2001.

Wordsworth, W., "Preface to the Lyrical Ballads" [1802], http://www.english.upenn. edu/ mgamer/Etexts/lbprose.html\#preface, 23.1.2010. 


\title{
PREDRAG KRSTIĆ
}

Institute for Philosophy and Social Theory, University of Belgrade

\section{ROMANTICIZING OR ROMANTIC DENIAL OF ENLIGHTENMENT?}

\begin{abstract}
The article argues that early Romanticism, articulating its own view, addresses to the Enlightenment an "aesthetic" remark which be traced deep into the twentieth century. The author of the work found it, after Schlegel and his school, not only in Weber 's diagnosis of institutionalized rationality of Western civilization, and in the Horkheimer's and Adorno's Dialectic of Enlightenment and the critique of the goal-oriented or instrumental reason of modernity that followed, but in a different way, also in Foucault, Böhme brothers, and even in postmodern philosophy and neopragmatism. It is concluded that all these orientations share detection of the lack od self-enlightenment of the Enlightenment and, consequently, the lack of its self-referential correction. These unaccounted costs of violations the Enlightenment committed to its "other", irreversibly or somehow still recoverable, undermines its original critical and emancipatory program.
\end{abstract}

Keywords: Enlightenment, Romanticism, rationality, organization, domination, art 